F. med. Genet. (1965). 2, 18.

\title{
Glucose-6-Phosphate Dehydrogenase (G6PD) Deficiency, Thalassaemia, and Abnormal Haemoglobins in Taiwan*
}

\author{
A. G. MOTULSKY, TING-CHIEN LEE, and G. R. FRASER $\dagger$
} From the Departments of Medicine and Genetics, the University of Washington, Seattle, and the Department of $\overrightarrow{\vec{\omega}}$
Pediatrics, National Taiwan College of Medicine, Taipeh, Taiwan

During 1960 blood samples were obtained from 300 male Taiwanese in Taipeh, Chi-Chi, and Chung-Li. The majority of donors were normal adolescents and adults whose blood was taken in district health centres and factories. A few hospital patients with diseases necessitating operation were included in Taipeh. The 98 from Taipeh were urban non-tribal persons and originated in all parts of Taiwan. Chung-Li (centre of island) and Chi-Chi (N.W.) on the other hand are small communities that cannot be regarded as representative of Taiwan as a whole. All the persons whose bloods were examined are descendants of Chinese from Fukien province who had immigrated into Taiwan in the 17 th century and later. Venous samples of blood were collected into ACD solution and sent to Seattle by air in ice-cooled vacuum flasks. They arrived within $24-48$ hours in excellent condition.

Since Taiwan was until recently an area with a high endemicity of falciparum malaria, the chief interest of this study was to determine the prevalence of G6PD deficiency, thalassaemia, and abnormal haemoglobins. The opportunity was taken of determining blood and serum group frequencies of which relatively little is known in the Taiwanese population. These are reported in a companion paper.

\section{G6PD Deficiency}

Nine of the 300 males showed unmistakable evidence by the brilliant cresyl blue decolorization test (Motulsky and Campbell-Kraut, 196I) of G6PD deficiency. This frequency of 0.03 for the sex-linked gene for G6PD deficiency compares

Received February 6, 1964

* This study was supported by U.S. Public Health Service Grant H 3091 .

$\dagger$ Present address: Department of Ophthalmology, Royal College of Surgeons, Lincoln's Inn Fields, London W.C.2. with 0.02 found by Vella (1959) among Chineseô in Singapore but only 0.003 in another survey in? Taiwan(Lee, Shih, Huang, Lin, Blackwell, Blackwell, $\cdot \overrightarrow{-}$ and Hsia, 1963). A more recent survey (Lee, unpub- $\infty$ lished) detected 90 deficient individuals among응 2,160 males-a gene frequency (0.04I) similar to that reported in this paper. In the same study, $\frac{3}{3}$ however, the incidence of G6PD deficiency among recent immigrants from the Chinese mainland to Taiwan was 0.018 and that among Hakka Chinese who came to Taiwan in the 16th and 17 th centuryer from Kwangtung and not Fukien province was no less than 0.055 .

It is likely that G6PD deficiency is of clinical significance in Taiwan. Among 4I children witho acute haemolytic anaemia admitted to the National $\stackrel{2}{\Omega}$ Taiwan University Hospital in recent years, $37 \stackrel{2}{\nexists}$ were boys and 4 were girls. The low ratio of girls is entirely compatible with similar findings in Favism and drug haemolytic anaemias caused by the sexlinked G6PD deficiency in Greece and Sardinia. The aetiological agents in Taiwan were not quite clear but included sulpha drugs in some cases.

In order to define the nature of the gene deter- 3 . mining G6PD deficiency in Chinese, a family originating from Canton, in Kwangtong province, 3 and living in Seattle was studied more thoroughly.o The proband was an enzyme-deficient boy ascer-? tained during a screening survey among Seattleo schoolchildren. He showed an enzyme level of zero when measured by the method of Zinkham, or Lenhard, and Childs (1958). Furthermore theN decolorization time, using the brilliant cresyl blueN test, was more than six hours. Such results are not $\sigma$ normally found in Negroes, among whom enzymedeficient males have a decolorization time of $2-4 \frac{\circ}{\circ}$ hours and 10-15\% of G6PD activity on quantitative testing. When these studies were done, electrophoretic and enzymological characterization of ${ }^{\circ}$

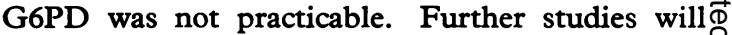
have to decide whether the Chinese variant of the $\frac{\text { Pे }}{8}$ 
gene for G6PD deficiency like that in the Philippines (Motulsky, Stransky, and Fraser, 1964) and in the Melanesians of New Guinea (Kidson and Gorman, 1962) is identical or different from that seen in Mediterranean (Greek, Italian) rather than Negro subjects. It is of interest that this boy's heterozygous mother and sister had enzyme levels well below the lower limits sually seen in Negro heterozygous females in the same laboratory.

\section{Abnormal Haemoglobins}

No major haemoglobin component other than normal haemoglobin A was found by paper electrophoresis of haemolysates. It is of interest that Blackwell and Huang (1963) studied 655 Taiwanese aborigines also without finding any abnormal haemoglobins.

\section{Thalassaemia}

Osmotic fragility of red blood cells in $0.45 \%$ $\mathrm{NaCl}$ was used as a screening test. The results expressed as percentage of lysis followed a normal distribution on the whole. 28 persons, however, with an increased osmotic resistance (percentage of lysis less than $75 \%$ ) lay outside this main distribution. These were further examined for foetal (F) haemoglobin levels by the alkaline denaturation technique (Singer, Chernoff, and Singer, I951a, b) and screened for haemoglobin $\mathrm{A}_{2}$ level by cyanogum electrophoresis (Raymond and Weintraub, 1959). In 12 of these 28 subjects visual examination of the cyanogum gel suggested a possible increase above normal in haemoglobin $A_{2}$ levels. An exact estimate of the proportion of haemoglobin present as $A_{2}$ was obtained by elution following

\section{TABLE I}

FINDINGS IN 9 SUBJECTS WITH PROBABLE $\beta$ THALASSAEMIA TRAIT

\begin{tabular}{|c|c|c|c|}
\hline Age & $\begin{array}{l}\text { Osmotic } \\
\text { Fragility } \\
\text { (\% lysis) }\end{array}$ & HbF $\% *$ & $\mathrm{HbA}_{2} \% \dagger$ \\
\hline $\begin{array}{l}21 \\
16 \\
28 \\
24 \\
52 \\
53 \\
33 \\
49 \\
19\end{array}$ & $\begin{array}{l}23 \\
67 \\
26 \\
24 \\
69 \\
60 \\
10 \\
30 \\
41\end{array}$ & $\begin{array}{l}0.4 \\
0.4 \\
0 \cdot 3 \\
0.3 \\
0.3 \\
1 \cdot 0 \\
4 \cdot 0 \\
1 \cdot 7 \\
1 \cdot 8\end{array}$ & $\begin{array}{l}5 \cdot 3 \\
3 \cdot 8 \\
3 \cdot 6 \\
4 \cdot 6 \\
4.5 \\
3 \cdot 3 \\
4 \cdot 9 \\
5 \cdot 9 \\
4 \cdot 5\end{array}$ \\
\hline
\end{tabular}

Note: In all cases red blood cells showed morphological abnormalities typical of this condition.

* HbF levels above $2 \%$ are abnormal.

$\dagger \mathrm{HbA}_{2}$ levels above $3 \cdot 2 \%$ are abnormal under these conditions of testing. starch block electrophoresis in these 12 specimens (Gerald and Diamond, 1958). In 9 instances the presence of high levels of haemoglobin $\mathrm{A}_{2}$ was confirmed (Table I), and it may be assumed that these represent cases of $\beta$ thalassaemia trait. In all 9 cases examination of the blood film treated with Wright's stain revealed morphological abnormalities of the erythrocytes typical of this condition. A high level of haemoglobin F ( $>2.0 \%$ ) was seen in only one of these cases and $\mathrm{HbF}$ was not raised in any of the 19 remaining cases with lysis of less than $75 \%$. An additional 100 subjects with normal osmotic fragility were tested for increases of foetal haemoglobin by the alkaline denaturation technique. No abnormalities were found.

Thus an estimate of $3 \%$ as the prevalence of $\beta$ thalassaemia in Taiwan is obtained, but there is a possibility that this represents a minimum figure and that other types of thalassaemia exist among the remaining 18 cases with increased osmotic resistance. Though the usual type of $\beta$ thalassaemia trait is accompanied by an increased haemoglobin $\mathrm{A}_{2}$ level, it has been suggested that another type exists in which $A_{2}$ levels are normal or even low due to interference with $\delta$ as well as $\beta$ chain synthesis (Fessas, 1963). The screening techniques employed here could not have definitely identified cases of this condition, though the absence of high levels of HbF with which it is usually associated suggests that it is not present in this population.

It seems more likely in view of the work of LieInjo, Lie, Ager, and Lehmann (1962) on the prevalence of $\alpha$ thalassaemia among persons of Chinese ancestry that some cases of this condition were not identified. Though paper electrophoresis revealed no examples of haemoglobin $\mathrm{H}$ or haemoglobin Bart's, this is not an adequate screening technique (Fessas, 1963). Again, though haemoglobin $\mathbf{H}$ inclusion bodies were searched for routinely following incubation with Coleman-Bell brilliant cresyl blue (Gouttas, Fessas, Tsevrenis, and Xefteri, I955), the inevitable delay of 48 hours that occurred between taking the blood and this examination much reduced the chances of positive findings even in $\alpha$ thalassaemia trait carriers. It may well be, therefore, that several of the 18 persons with increased osmotic resistance but normal haemoglobin $A_{2}$ levels were such carriers. However, the extent of iron-deficiency in this male, largely adolescent, and adult population is not known, and anaemia due to this cause could give similar findings.

In view of suggestions that malaria plays a role in the maintenance of G6PD deficiency and thalas- 
saemia by increased resistance of gene carriers, it might be expected that a greater than chance proportion of persons affected simultaneously with both conditions might be found in the population. In fact, of the 9 thalassaemic subjects in Table I, one only is G6PD deficient. Though the expected frequency of such persons is only $I$ in a $I, 000$, the observed incidence of $I$ in 300 clearly cannot be taken, in the absence of further evidence, to be significant. A similar slight excess was found by Bernini, Carcassi, Latte, Motulsky, Romei, and Siniscalco (1960).

\section{Summary}

G6PD deficiency and $\beta$ thalassaemia trait were found in equal frequencies in a population of 300 Taiwanese Chinese males (approximately $3 \%$ of each). No abnormal major haemoglobin components were found.

We should like to acknowledge the expert technical assistance of Mrs Jackie Keil.

\section{REFERENCES}

Bernini, L., Carcassi, U., Latte, B., Motulsky, A. G., Romei, L., and Siniscalco, M. (1960). Indagini genetiche sulla predisposizione al favismo. III. Distribuzione delle frequenze geniche per il locus $\mathrm{Gd}$ in Sardegna. Interazione con la malaria e la talassemia al livello popolazionistico. Accademia Nationale dei Lincei, 29, $\mathrm{x}$.

Blackwell, R. Q., and Huang, J. T. (1963). Abnormal hemoglobin studies in Taiwan aborigines. Science, 139, 771 .
Fessas, P. (1963). Screening methods in population studies of the different thalassaemia types. In Genetics of Migrant and Isolate Populations, ed. E. Goldschmidt, p. 56. Williams and $\underset{\mathscr{D}}{+}$ Wilkins, New York.

Gerald, P. S., and Diamond, L. K. (I958). The diagnosis of thalassaemia trait by starch block electrophoresis of the haemoglobin. ? Blood, 13, 6r.

Gouttas, A., Fessas, P., Tsevrenis, H., and Xefteri, E. (1955). Description d'une nouvelle variété d'anémie hémolytique congénitale; étude hématologique, électrophorétique et génétique. $\frac{\omega}{7}$ Sang, 26, 911 .

Kidson, C., and Gorman, J. G. (1962). Contribution of red cell@ enzyme deficiency trait to an understanding of genetical relation- 0 ship between Melanesian and other populations. Amer. F. phys. ${ }^{\circ}$ Anthrop., 20, 357.

Lee, T. C., Shih, L. Y., Huang, P. C., Lin, C. C., Blackwell, B. N.,' Blackwell, R. Q., and Hsia, D. Y. Y. (1963). Glucose-6-phos- $\overrightarrow{\vec{\omega}}$ phate dehydrogenase deficiency in Taiwan. Amer.f. hum. Genet.,

Lie-Injo, L. E., Lie, H. G., Ager, J. A. M., and Lehmann, H. (1962). $\alpha$-thalassaemia as a cause of hydrops foetalis. Brit. $\mathcal{F}$

Haemat., 8, 1.
Motulsky, A. G., and Campbell-Kraut, J. M. (1961). Population genetics of glucose-6-phosphate dehydrogenase deficiency of the red cell. In Proceedings of the Conference on Genetic Polymorphisms $\vec{\infty}$ and Geographic Variations in Disease, ed. B. Blumberg, p. 159.0 Grune and Stratton, New York.

, Stransky, E., and Fraser, G. R. (1964). Glucose-6-phosphatedehydrogenase (G6PD) deficiency, thalassaemia, and abnormal $Z$ haemoglobins in the Philippines. F. med. Genet., 1, 102.

Raymond, S., and Weintraub, L. (1959). Acrylamide gel as a supporting medium for zone electrophoresis. Science, 130, 71 I.

Singer, K., Chernoff, A. I., and Singer, L. (1951a). Studies onabnormal haemoglobins. I. Their demonstration in sickle celle anemia and other hematologic disorders by means of alkali de-G naturation. Blood, 6, 413.

II. $\frac{}{\text { Their identification }}, \frac{\text { Studies on abnormal hemoglobins. }}{\square}$ denaturation. ibid., 6, 429.

Vella, T. (1959). Favism in Asia. Med. F. Aust., 2, 196.

Zinkham, w. H., Lenhard, R. E., Jr., and Childs, B. (1958). Aمे deficiency of glucose-6-phosphate dehydrogenase activity in erythrocytes from patients with favism. Bull. Fohns Hopk. Hosp., 102, 169 . 